\title{
Adam Chmielecki
}

\section{"MAŁA OJCZYZNA" \\ MACIEJA PŁAŻYŃSKIEGO (1958-1977)}

\section{Chłopak z Warmii}

Młynary to małe miasto położone w północno-zachodniej części województwa warmińsko-mazurskiego, w obrębie Wzniesień Elbląskich, w powiecie elbląskim, niemal dokładnie na historycznym pograniczu Warmii i Prus Książęcych (Prus Górnych) ${ }^{1}$. Miejscowość została załóżona pod spolszczoną później nazwą Mühlhausen w $1327 \mathrm{r}$. na prawie chełmińskim przez osadników niemieckich z Turyngii (zasadźcą miał być niejaki Mikołaj Kunim)2.W XIV i XV w. wchodziła Ws skład państwa zakonu krzyżackiego jako siedziba zarządu lasów komturii elbląskiej. Komtur elbląski Herman Oetingen był wystawcą aktu lokacyjnego Młynar³. W 1628 roku miasto zostało zajęte i ograbione przez wojska szwedzkie, z kolei w 1807 r. stacjonowały w nim wojska francuskie cesarza Napoleona Bonaparte. Miejscowość jednak sukcesywnie podupadała i traciła na znaczeniu, straciła też prawa miejskie, które odzyskała dopiero w 1984 r. Przywrócono wówczas herb miasta, na którym widnieje złote drzewo wpisane w srebrne koło młyńskie, umieszczone na błękitnym polu. Kolory te symbolizują czystość i prawdę (srebrny), lojalność i wierność (błękitny) oraz wiarę, mądrość i chwałę (złoty). Obecnie miasto nad rzeką Baudą liczy niespełna 2 tys. mieszkańców ${ }^{4}$.

To właśnie w Młynarach, wówczas wciąż jeszcze wsi, 10 lutego 1958 r. urodził się Maciej Płażyński, polityk, którego większość działalności publicznej i ży-

${ }^{1}$ J. Białobrzeski, Młynary. Małe miasto 1327-2007, Olsztyn 2008, s. 1.

250 lat Szkoły Podstawowej im. Stefana Żeromskiego w Młynarach, bdm, s. 5. Nieliczne inne źródła podają, że miasto zostało założone dwa lata później, w 1329 r., przez Krzyżaków. Za oficjalną datę powstania miejscowości uznaje się jednak $1327 \mathrm{r}$. Taką wersję uwiarygodnia fakt istnienia w Turyngii miejscowości Mühlhausen, której nazwę tamtejsi osadnicy mieli przenieść na osadę założoną w Prusach. Por. Historia Młynar, http: //www.mlynary.pl/index.php?pod_menu=12 (dostęp: 1 VI 2015).

${ }^{3}$ Na podstawie tego aktu w 1338 r. wielki szpitalnik zakonu krzyżackiego i nowy komtur elbląski Zygfryd von Sicken odnowił Młynarom przywileje miejskie. Zob. 50 lat Szkoły Podstawowej..., s. 5.

${ }^{4}$ Według danych Głównego Urzędu Statystycznego, w 2012 r. gmina miejsko-wiejska Młynary liczyła 4591 mieszkańców, a same miasto 1859. Zob. Ludność. Stan i struktura w przekroju terytorialnym. Stan w dniu 30 VI 2012 r., Warszawa 2012, s. 98. 
cia prywatnego związana była z odległą o 83 kilometry stolicą Pomorza - Gdańskiem. Jan Korsak, najbliższy przyjaciel Macieja Płażyńskiego z dzieciństwa, tak wspominał ich wspólną małą Ojczyznę:

Nasza rodzinna miejscowość, Młynary, leży na obszarze Warmii i Mazur, niedaleko obwodu kaliningradzkiego, który w tamtym czasie był zamknięty dla jakiegokolwiek ruchu. Mieszkaliśmy na peryferiach naszego kraju. Tutaj przebiegała granica. To nie było miejsce po drodze, tam się tylko dojeżdżało - pociągi kończyły bieg w pobliskim Braniewie. Choć przed wojną Młynary były dość prężnym ośrodkiem, to przez zniszczenia wojenne podupadły i utraciły nawet prawa miejskie, które dopiero po latach odzyskały. Mieszkańcami byli głównie repatrianci, zresztą rodzice Macieja również pochodzili gdzieś ze Wchodu. Była to mieszanka różnych społeczności z wielu miejsc, z Kresów i z innych regionów Polski. Była to miejscowość stanowiąca wypadkową różnych stylów, tradycji i kultur. Niezwykle ważną rolę odgrywały tu szkoła i Kościół - dwa ośrodki mające ogromny wpływ na wychowywanie młodego pokolenia ${ }^{5}$.

Maciej Płażyński przyszedł na świat jako drugie dziecko w inteligenckiej rodzinie Danuty ż Kościańskich (ur. 1930 r.) i Wojciecha Płażyńskiego (1927-1999). Poród miał miejsce $\mathrm{w}$ domu. Ojciec miâl już pierwōrodnego synā, Wojciecha, urodzonego w 1956 r., marzył więc o córce. Dużo wcześniej wybrał już nawet imię dla przyszłego potomka płci żeńskiej - Katarzyna. Gdy akuszerka tuż po narodzinach Macieja poinformowała, że urodził się drugi syn, Wojciech Płażyński był jednak dumny i szczęśliwy. Położna znała jego wcześniejsze oczekiwania, powiedział więc do niej nieco żartobliwie: „Dobre i to"6.

Matka Macieja Płażyńskiego pochodziła z Wielkopolski, z Kalisza. Ojciec ze wschodniej Polski, z Lublina. Oboje otrzymali po studiach nakaz pracy. Były to lata pięćdziesiąte XX w., na tzw. Ziemiach Odzyskanych potrzebni byli fachowcy. Młoda lekarka weterynarii i jej kolega po fachu dzięki skierowaniom, które w PRL spełniały często rolę swoistego przeznaczenia, spotkali się w Nidzicy. Później oboje mieszkali i pracowali krótko w Szczytnie na Mazurach?7.

Po ślubie w 1953 r. Płażyńscy przeprowadzili się do Młynar, gdzie 1 kwietnia 1956 r. Wojciech został kierownikiem Lecznicy Weterynaryjnej Zwierząt. Był to duży zakład, w którym pracowało także dwóch innych lekarzy weterynarii (w tym Danuta Płażyńska jako ordynator przychodni), technik weterynarii, pielęgniarz, sekretarka i kierowca ${ }^{8}$. Przychodnia składała się m.in. z sali zabiegowej,

${ }^{5}$ J. Korsak, Człowiek z Młynar, w:, Moim powołaniem jest służba publiczna. Rzecz o Macieju Płażyńskim, Warszawa 2013, s. 20.

${ }^{6}$ Relacja D. Płażyńskiej, 8 III 2014, w zbiorach autora.

${ }^{7}$ A. Chmielecki, Dzieciństwo, miłość, rodzina, w:, Moim powołaniem jest służba publiczna..., s. 16.

${ }^{8}$ J. Białobrzeski, op. cit., s. 259. 
apteki i garażu dla służbowej Syreny 101. Samochód był niezbędny, ponieważ weterynarze kierowani przez Wojciecha Płażyńskiego obsługiwali teren dwóch gmin - Młynary i Wilczęta. Pracy nie brakowało, gdyż na tych terenach dynamicznie rozwijała się hodowla zwierząt. Lecznica mieściła się w tym samym budynku przy ul. Konarskiego 1 w Młynarach, w którym mieszkała rodzina. Duży, ale zniszczony i zaniedbany, poniemiecki budynek, przekazany przez gminę, gruntownie wyremontował osobiście Wojciech Płażyński.

Co ciekawe, zawód lekarza weterynarii wykonywali również dwaj wujkowie Macieja Płażyńskiego, bracia mamy - Mirosław Kościański (w Olsztynie) i Teodor Kościański (w Braniewie). W efekcie Maciej Płażyński oraz jego starszy brat Wojciech wynieśli z domu rodzinnego nie tylko miłość do zwierząt, ale również fachową, wręcz naukową wiedzę na temat ich zachowania, charakteru, sposobu opieki itd. Maciej Płażyński kochał zwłaszcza psy, ale był wrażliwy na krzywdę wszystkich zwierząt. Te, które spotkał w okolicy Młynar chore lub ranne, jak wspominał jego brat, $z$ oddaniem zanosił do lecznicy rodziców:

Pisklaki, koty, pieski wymagajace pomocy ciagle podtykał rodzicom i prosił, żeby je leczyć. Ostatecznie to ja zostałem weterynarzem, a on swoją wrażliwość skierował na obronę pokrzywdzonych i został politykiem'.

W dzieciństwie pupilem Macieja Płażyńskiego był rodzinny jamnik. W kolejnych latach również nie wyobrażał sobie życia bez zwierząt. Gdy założył swoją rodzinę, jednym z domowników zawsze był pies. Płażyński wyłamał się jednak $z$ rodzinnej tradycji zawodowej i został politykiem, a nie weterynarzem. Własną lecznicę dla zwierząt prowadzi za to do dziś w Braniewie jego brat Wojciech.

W 1976 r. Danuta Płażyńska objęła stanowisko kierownika laboratorium weterynaryjnego w odległym o 15 km od Młynar Pasłęku. Wkrótce, w 1978 r., wspólnie z mężem przeniosła się do Ornety, gdzie również prowadzili lecznicę weterynaryjną, w ramach Terenowego Zakładu Weterynarii w Braniewie ${ }^{10}$. Maciej Płażyński był już wówczas od roku w Gdańsku na studiach prawniczych. Dlatego, chociaż formalnie był w tym czasie zameldowany w domu rodziców w Ornecie przy ul. Kopernika 19, to Młynary pozostały dla niego na zawsze domem rodzinnym i miejscem, do którego wracał wspomnieniami z dzieciństwa.

A był to w jego życiu okres ciekawy, nieszablonowy i rozwijający, a przy tym zaskakujący w kontekście przyszłej działalności publicznej. Obaj bracia Pła-

\footnotetext{
${ }^{9}$ Brat Macieja Płażyńskiego, Wojciech Płażyński: Żegnaj Braciszku!, Se.pl, http://www.se.pl/wiadomosci/ polska/brat-wojciecha-plazynskieg-zegnaj-braciszku_136526.html, 16 IV 2010 (dostęp: 1 VI 2015).

${ }^{10}$ Przychodnię w Młynarach przejął po nich jeden z pracowników - lek. wet. Ryszard Cukiernik. Zob. J. Białobrzeski, op. cit., s. 446. Danuta i Wojciech Płażyńscy przeszli na emeryturę w drugiej połowie lat 80 . XX w.
} 
żyńscy mieli w domu konkretne obowiązki, z których byli rozliczani. Mieli trochę czasu na nieposłuszeństwo i młodzieńcze roztargnienie wtedy, gdy rodzice wyjeżdżali na dłuższe wizyty weterynaryjne w teren. W domu państwa Płażyńskich w latach sześćdziesiątych i siedemdziesiątych pracowała jeszcze jako gosposia i pomoc domowa Freda Kenig, Niemka, która nie tak jak większość autochtonów z terenów Warmii i Mazur nie wyemigrowała po II wojnie światowej do Niemiec. Pomagała pani Płażyńskiej prowadzić gospodarstwo domowe, pielęgnować ogródek itd. Pod nieobecność mamy to ona pilnowała porządku i dyscypliny w domu, jednak obaj bracia, zwłaszcza Maciej, nie uznawali jej autorytetu nad sobą. Niemka słabo mówiła po polsku, zatem przyszły polityk, dzięki kilkuletnim kontaktom, nauczył się języka niemieckiego na całkiem przyzwoitym poziomie. Freda Kenig sumiennie wykonywała swoje obowiązki i zżyła się z całą rodziną. Danuta i Wojciech Płażyński doceniali jej oddanie. Opłacali jej składki na ubezpieczenie społeczne, dzięki czemu uzyskała potem prawa do emerytury. Nawet Maciej po latach z sympatią wspominał jej obecność w rodzinnym domu ${ }^{11}$.

Młody Maciej Płazyński miał bujną blond czüprynę. Jakō nastolatek nosił długie włosy, sięgające do ramion, i długą grzywkę zakrywająca niemal całe czoło. Chociaż rozwijał się szybciej od rówieśników, był niskim chłopcem, przez co do pewnego wieku miał nawet kompleks. Wyrósł dopiero w okresie szkoły średniej. Mimo tego, obcował ze starszymi od siebie. W bardziej dorosłe towarzystwo wciągał go także brat Wojciech. To jego klasowym kolegą był wspomniany już najbliższy przyjaciel Macieja Jan Korsak, późniejszy prezes Polskiej Organizacji Turystycznej.

[Maciej] był zadziornym, niezwykle dynamicznym i kreatywnym chłopcem, z którym się przyjaźniliśmy. Z jego starszym bratem dzieliliśmy ławę szkolną, a Maciej był dwa czy trzy lata młodszy i w związku z tym czasami odstawał od naszej grupy, jednak nadrabiał ten dystans ciekawą osobowością ${ }^{12}$.

Rytm życia młodego Maćka Płażyńskiego wyznaczały szkoła, Kościół i piłka nożna. Chociaż w Młynarach mieszkało dużo ludności napływowej, podobnej do rodziny Płażyńskich, życie upływało tam według reguł tradycyjnej pobożności katolickiej Warmii. Przypomnijmy słowa historyka Władysława Konopczyńskiego, który pisał, że „Warmia zawisła na kształt katolickiego półwyspu w protestanckie księstwo pruskie"13.

\footnotetext{
${ }^{11}$ Relacja D. Płażyńskiej.

${ }^{12}$ J. Korsak, op. cit., s. 20.

${ }^{13}$ W. Konopczyński, Dzieje Polski Nowożytnej, Warszawa 1996, s. 318, cytat za ks. S. Ewertowski, Kulturowy i gospodarczy wymiar „świętych miejsc” regionu Warmii i Mazur, Studia Warmińskie, 2010, nr XLVII, s. 111.
} 
Jednym z najważniejszych miejscowych autorytetów w Młynarach w czasach dzieciństwa i młodości Płażyńskiego był ks. Czesław Barwicki, w latach 1964-1974 proboszcz parafii św. Piotra Apostoła w Młynarach, wilniuk z pochodzenia, który po II wojnie światowej spędził osiem lat w sowieckim łagrze na terenie dzisiejszego Kazachstanu.

Bardzo ważną rolę w procesie naszego wychowania odegrał także proboszcz tutejszej parafii, śp. ks. Czesław Barwicki, który był silną osobowością - wspominał Jan Korsak - były więzień łagrów, jako młody kapłan z przedwojennych kresów został wywieziony do Kazachstanu, a po powrocie stamtąd znaczną część swego życia spędził w Młynarach. Mieliśmy szczęście do osób, które w niezwykle pozytywny i mądry sposób oddziaływały na nas, dając szansę rozwoju wszystkim tym, którzy chcieli z tego skorzystać. Z tym czasami odstawał od naszej grupy, jednak nadrabiał ten dystans ciekawą osobowością ${ }^{14}$.

Zgodnie z miejscowym zwyczajem, codziennie rano w drodze do szkoły Maciej Płażyński, wspólnie z bratem i Janem Korsakiem, wstępowali na krótką modlitwę do drugiego kościoła w Młynarach, pw. Niepokālañego Poczęcia Najświętszej Maryi Panny (należącego do parafii pw. św. Piotra Apostoła). Z takich drobnych rytuałów i kontaktów z autorytetami zrodziła się głęboka, ale nie afiszowana przesadnie, wiara chrześcijańska Macieja Płażyńskiego.

Przyszły wojewoda gdański znajdował oczywiście także czas na rozrywkę i rozwój fizyczny. Uwielbiał oglądać westerny w objazdowym kinie, które co jakiś czas zajeżdżało do Młynar. Miłość do filmów o Dzikim Zachodzie, w przygodowej konwencji przedstawiającej walkę dobra ze złem, pozostała mu na całe życie. Jak wielu rówieśników, w młodości chciał zostać sławnym piłkarzem. Zaczęło się od codziennego grania w piłkę z kolegami na boisku sąsiadującym $\mathrm{z}$ domem rodzinnym. Później rozpoczął bardziej profesjonalne, regularne treningi w miejscowym klubie Syrena Młynary. „Czerwono-Czarni” powstali w 1949 r., ale dopiero kilka lat przed narodzinami Macieja Płażyńskiego, w 1955 r., powstało nowe boisko z prawdziwego zdarzenia, na którym Syrena Młynary rozgrywała mecze w okręgowej Klasie $B^{15}$. Przyszły marszałek Sejmu grał na pozycji środkowego obrońcy. Barwy Syreny reprezentował również jego brat Wojciech. Zdaniem kolegów z dzieciństwa, obaj „zaliczali się do najlepszych graczy swojego pokolenia” w okolicy ${ }^{16}$, chociaż Wojciech Płażyński przyznawał, że z większym zaangażowaniem i skutecznością uprawiał futbol jego młodszy brat ${ }^{17}$.

${ }^{14}$ J. Korsak, op. cit., s. 20. Zob. także: Bp J. Wojtkowski, Kapłani Archidiecezji Warmińskiej zmarli w latach 1992-2002, „Studia Warmińskie”, 2003, nr XL, s. 471.

${ }^{15}$ Klub Sportowy Syrena Młynary, http://syrena.futbolowo.pl/menu,2,o-klubie.html, dostęp 1 VI 2015.

${ }^{16}$ J. Korsak, op. cit., s. 21.

${ }^{17}$ Brat Macieja Płażyńskiego... 
Pasja do piłki nożnej i całego sportu pozostała Maciejowi Płażyńskiemu już na zawsze. Koledzy z liceum w Pasłęku zapamiętali go przychodzącego do szkoły z „Przeglądem Sportowym” pod pachą. Na studiach grał w drużynie Akademickiego Związku Sportowego Gdańsk. W latach osiemdziesiątych był filarem obrony drużyny konserwatystów (młodo polaków) w słynnych meczach działaczy trójmiejskiej opozycji antykomunistycznej. Później z racji obowiązków rodzinnych i zawodowych raczej kibicował niż pojawiał się na boisku. Był wiernym fanem reprezentacji Polski, Lechii Gdańsk i Realu Madryt, a sam grywał w okazjonalnych spotkaniach VIP-ów, np. w piłkarskiej reprezentacji polskich parlamentarzystów.

\section{Korzenie - Kresy i Wielkopolska}

O ile sam Maciej Płażyński, w kontekście całej swojej drogi życiowej kojarzony powszechnie jako obywatel Gdańska i Pomorza, pochodził z Warmii, o tyle korzenie jego rodziny sięgają jeszcze dalej. Warto krótko wspomnieć o przodkach pierwszego niekomunistycznego wojewody gdańskiego, ponieważ reprezentują oni dwie główne tradycje (kulturalne, społeczne i polityczne) dominujące nad polską historią od kilku stuleci - romantyczną i realistyczną (pozytywistyczną). Rodzina Płażyńskich wywodzi się z południowo-wschodnich Kresów Rzeczypospolitej, a konkretnie z Czernichowic w przedwojennym województwie tarnopolskim. To stąd pochodził jego pradziadek Maksymilian Płażyński. Późniejsze zaangażowanie marszałka w sprawy Polonii, zwłaszcza na Wschodzie, miało w sobie także zatem wymiar osobisty - niejako powrotu w rodzinne strony, odkrywania źródeł własnej tożsamości.

O losach Maksymiliana Płażyńskiego wiadomo niewiele. W rodzinnych archiwach nie zachowały się żadne dokumenty na jego temat. Nic dziwnego, w końcu trasa kilkupokoleniowego rodzinnego exodusu z Tarnopola (obecnie w Obwodzie Tarnopolskim na Ukrainie) do Młynar liczyła blisko 800 km, a „po drodze” miały miejsce rewolucje i dwie wojny światowe. W przekazie rodzinnym zachowała się tylko informacja, że pradziadek Macieja Płażyńskiego zginął w wypadku samochodowym w Stanisławowie. Jego syn, dziadek Macieja Płażyńskiego, przyszedł na świat w 1895 r. i również otrzymał imię Maksymilian. W czasie I wojny światowej służył w słynnym 1 Pułku Ułanów Legionów Polskich, zwanym „beliniakami”18. Określenie wzięło się od nazwiska dowódcy, Władysława „Beliny” Prażmowskiego,

${ }^{18}$ Biogram Maksymiliana Płażyńskiego, Wykaz Legionistów Polskich 1914-1918, Muzeum Józefa Piłsudskiego w Sulejówku, http://mjp.najlepszemedia.pl/wykaz-legionistow/wykaz/legionista/19859-plazynski, dostęp 1 VI 2015. 
który w nocy z 2 na 3 sierpnia 1914 r. na czele sześcioosobowego oddziału ułanów (z braku koni poruszali się bryczką) wyruszył na patrol zwiadowczy, przekraczając granicę Austro-Węgier i Królestwa Polskiego.„,Siódemka Beliny” stała się tym samym awangardą walki o odrodzenie wolnej Polski po latach zaborów. Chociaż Maksymilian Płażyński nie znalazł się w pierwszym doborowym oddziale wybranym przez „Belinę”, służba w 1 Pułku Ułanów była zaszczytem. Przechodząc szlak bojowy z Legionami Polskimi, dziadek Macieja Płażyńskiego, zgodnie z legionowym zwyczajem, przyjął pseudonim „Jastrzębiec”, który z czasem stał się niemalże pełnoprawną częścią jego nazwiska. Po odzyskaniu przez Polskę niepodległości w 1918 r. Maksymilian „Jastrzębiec” Płażyński pozostał w Wojsku Polskim jako oficer w 17 Pułku Ułanów Wielkopolskich. Okoliczności jego tragicznej śmierci w 1927 r. nie są do końca znane - prawdopodobnie zginął w pojedynku lub popełnił samobójstwo z nieznanej przyczyny. W każdym razie, co podkreśla się w przekazach rodziny Płażyńskich, była to śmierć honorowa, godna przedwojennego oficera Wojska Polskiego. Trzy lata wcześniej, w1924 r. w Lublinie urodził się ojciec Macieja Płażyńskiego - Wojciech. W czasie II wojny światowej wspólnie z bratem Mäksymilianem (ur. 1927 r.) działał w konspiracji niepodległościowej na Lubelszczyźnie, należał do Armii Krajowej, w Lotnym Oddziale Partyzanckich Obwodu AK Lublin, wchodzącym w skład 8 pułku piechoty Armii Krajowej, dowodzonym przez por. Wojciecha Rokickiego „Nerwę. Maksymilian Płażyński, stryj Macieja, zginął z rąk Niemców w lutym 1944 r. w pobliżu wsi Abramowice niedaleko południowych rogatek Lublina. Nie była to akcja bojowa. Grupa polskich żołnierzy przewoziła saniami broń dla komendy AK w Lublinie, gdy natknęli się na oddział niemieckiej policji, wywiązała się strzelanina, w której zginęło trzech Polaków, wśród nich Maksymilian Płażyński ${ }^{19}$. Ich śmierć została zapamiętana przez kolegów z Armii Krajowej.

Mamy jeszcze w żywej pamięci tragiczną śmierć naszych kolegów z partyzanckiego oddziału AK porucznika „Nerwy”, którzy przed Wielkanocą tego roku otrzymali przepustkę i po szpersztundzie przedzierali się do miasta na święta do rodziny. Przyłapani na rogatce Lublina przez patrol żandarmerii niemieckiej byli ciągnięci na linie za motocyklem aż na ulicę Wieniawską. Tam ich zmasakrowane zwłoki wyrzucono przez mur na śmietnisko. Tak zginęli bohaterowie Maksymilian Płażyński ze swoim kolegą. Taki los czekał każdego, kogo przechwycą żandarmi ${ }^{20}$.

\footnotetext{
${ }_{19}$ Zginęli także Stanisław Bałuk „Hak” i Tadeusz Łukawski. Uciec udało się tylko Bogdanowi Wójcickiemu „Wójtowi”. Zob. Oddział „Nerwy” - młodzi, dzielni, niezapomniani, http://www.gim1bychawa.pl/ downloads.php?cat_id=9\&download_id=41, dostęp 1 VI 2015.

${ }^{20}$ J. Sieradzon, Skok do piekła $i$ do nieba w lipcu 1944 r., Biuletyn Informacyjny Światowego Związku Żołnierzy Armii Krajowej Okręg Wielkopolska, 2008, nr 3, s. 38. W oryginale podano błędnie imię Maksymiliana Płażyńskiego jako „Wojciech”. Nieścisłości przytoczonej relacji należy tłumaczyć udostępnieniem jej w 1997 r., ponad 50 lat po opisywanych wydarzeniach, oraz wiedzą o niej autora relacji jedynie „z drugiej ręki”.
} 
Wojciech Płażyński przeżył wojnę, ale za swoją działalność niepodległościową w komunistycznej Polsce był inwigilowany przez bezpiekę ${ }^{21}$. Mimo tego przekazał synom akowską tradycję niepodłegłościową, która od wczesnych lat życia stanowiła dla nich swoisty wewnętrzny kordon, impregnujący obu na komunistyczną propagandę.

Notabene, przedwczesna i nienaturalna śmierć trzeciego mężczyzny o imieniu Maksymilian z rodu przerwała rodzinną tradycję nadawania chłopcom z kolejnych pokoleń tego imienia. Gdy w 1956 r. urodził się pierwszy syn Danuty i Wojciecha Płażyńskich, ojciec chciał nadać mu właśnie imię Maksymilian, jednak sprzeciwiła się temu pani Danuta, uznając je ze imię tragiczne ${ }^{22}$.

Maksymilian „Jastrzębiec" Płażyński i jego syn zostali pochowani w kwaterze wojskowej na cmentarzu komunalnym w Lublinie przy ul. Lipowej. W 2000 r. ich wnuk i bratanek, Maciej Płażyński, jako marszałek Sejmu oddał im cześć składając kwiaty na ich grobach ${ }^{23}$.

Rodzina mamy, czyli Kościańscy, pochodziła ze wschodniej Wielkopolski, z okolic Kalisza, Leszna i Košcíana. MaciejPłażyński niewiele wiiedział o swoich antenatach z tej linii. Dziadka, ojca mamy, Leona Kościańskiego, nie miał szansy poznac. Walczył on w powstaniu wielkopolskim, a w czasie II wojny światowej był zaangażowany w działalność konspiracyjną. W 1945 r. został aresztowany przez gestapo na dworcu kolejowym w Poznaniu, a następnie wywieziony do podobozu obozu koncentracyjnego KL Flossenbürg w Leitmeritz (obecnie miasto Litomierzyce w Czechach). Tam słuch po Leonie Kościańskim zaginął ${ }^{24}$. Maciej Płażyńskiego poznał za to babcię od strony mamy, żonę Leona Kościańskiego - Stefanię Kościańską (z domu Ordzińską). Była to elegancka i dobra, ale zasadnicza, wręcz apodyktyczna kobieta.

Już po tym krótkim przeglądzie dziejów obu rodów - Płażyńskich i Kościańskich - widać, że od pierwszych lat życia Maciej Płażyński wzrastał w środowisku pełnym polskich wartości i doświadczeń różnorodnych polskich losów. Rodzinne tradycje ze strony ojca niosły duchowe dziedzictwo dawnych Kresów I i II Rzeczypospolitej - romantyzmu, patriotyzmu, przywiązania do Boga i poczucia honoru. Rodzina mamy wniosła do jego świata tradycje pozytywistyczne - realizm, przywiązanie do pracy, porządku i dyscypliny, dobrą organizację. Gdy dekadę po zakończeniu II wojny światowej rodzice Macieja Płażyńskiego trafili na Mazury, a później Warmię, znaleźli się w tyglu etniczno-kulturowo-re-

${ }^{21}$ IPN Gd 0046/54 t. 1, Wykaz oświadczeń ujawnionych członków organizacji politycznych działających w okresie okupacji, Gdańsk, 20 V 1965, k.

${ }^{22}$ Relacja D. Płażyńskiej...

${ }^{23}$ RP, Marszałek na cmentarzu, Gazeta Wyborcza Lublin, 7 XI 2000.

${ }^{24}$ Relacja D. Płażyńskiej... 
ligijnym ziem, na których żyli obok siebie Polacy, Ukraińcy (przesiedleni na te tereny z południowo-wschodniej Polski w ramach Akcji „Wisła”) i nieliczni, ale jednak Niemcy; katolicy rzymscy i greccy, prawosławni oraz ewangelicy. Na te wszystkie doświadczenia cieniem położyła się jeszcze komunistyczna rzeczywistość Polskiej Rzeczpospolitej Ludowej.

Oboje rodzice Macieja Płażyńskiego nie angażowali się w tzw. wielką politykę. Jednak jako weterynarze niejako z urzędu w pewien sposób byli osobami publicznymi. Wykonywali zawód zaufania społecznego, który zwłaszcza w tak małych środowiskach lokalnych w pewien sposób zobowiązywał do udziału w miejscowym życiu publicznym, bez względu na wyznawany system wartości i poglądy polityczne. Dlatego zaangażowali się w działalność publiczną w Młynarach. W czerwcu 1969 r. Danuta Płażyńska została wybrana przewodniczącą Komisji Rolnictwa, Leśnictwa i Zaopatrzenia Ludności Gromadzkiej Rady Narodowej w Młynarach. Funkcję tę pełniła do 1973 r. Wówczas, w związku z wprowadzoną w całej Polsce reformą administracyjną, Gromadzka Rada Narodowa w Młynarach została przekształcona w Gminną Radę Narodową, a Danuta Płażyńska została jej przewodnicząca (od 3 stycznia 1973 r.). Jednak już 17 grudnia 1973 r. zrezygnowała z tego stanowiska. Została jednym z dwóch wiceprzewodniczących GRN w Młynarach. Nieco później, 17 października 1974 r., Danutę Płażyńską wybrano także na zastępcę przewodniczącego społecznej komisji pojednawczej. W kolejnej kadencji, od 16 lutego 1978 r., mama Macieja Płażyńskiego pozostała w składzie Prezydium Gminnej Rady Narodowej, została też przewodniczącą Komisji Rozwoju Gospodarczego i Zaopatrzenia. Obu funkcji zrzekła się 31 stycznia 1979 r. w związku ze zmianą miejsca zamieszkania i przeprowadzką do Ornety ${ }^{25}$. W latach edukacji swoich synów w szkole podstawowej w Młynarach Danuta Płażyńska udzielała się także w szkolnym komitecie rodzicielskim, również jako jego przewodnicząca ${ }^{26}$. Czy to właśnie zaangażowanie publiczne i społeczne na poziomie lokalnym zaprowadziło Danutę Płażyńską do członkostwa w partii komunistycznej (od listopada 1972 r. wchodziła ona w skład Komitetu Gminnego PZPR w Młynarach jako sekretarz rolny ${ }^{27}$ ).

\section{Wolny jak ptak}

Maciej Płażyński, jako wyjątkowo zdolny chłopiec, został posłany przez rodziców do szkoły podstawowej o rok wcześniej od swoich rówieśników, w 1964 r.

${ }^{25}$ J. Białobrzeski, op. cit., ss. 244-259, 267-268 i 285.

${ }^{26} 50$ lat Szkoły Podstawowej..., s. 51.

${ }^{27}$ J. Białobrzeski, op. cit., s. 413. 
Nie miał problemów z przechodzeniem do kolejnej wyższej klasy, ale nie przykładał się do nauki. Odróżniało go to od starszego brata, który był uczniem pilnym, obowiązkowym i w każdej szkole należał do ścisłej czołówki pod względem otrzymanych stopni.

Tymczasem Maciej Płażyński był uczniem niesfornym, często wagarującym, który świadomie nadużywał swojej zdolności szybkiej nauki i ogólnej bystrości. Wiedział, że z tego powodu może nieco bezkarnie pozwolić sobie na brak pracowitości i pilności. Stąd w jego dzienniczku często pojawiały się uwagi podobne do tych, jakie w klasie VIIa wystawiła jego wychowaczyni Krystyna Wiśniewska: „Przeszkadza w prowadzeniu lekcji”, „Na lekcji rzuca cukierkami”, „Nie reaguje na uwagi nauczyciela”, ,Uciekł z lekcji rysunku”, „Nie wykonuje poleceń nauczyciela”, „Pyskuje do nauczycieli”28. Często spóźniał się na lekcje, miał też co roku kilkadziesiąt godzin nieobecnych i nieusprawiedliwionych (tylko rodzice wiedzą, ile $\mathrm{z}$ godzin nieobecnych, ale usprawiedliwionych faktycznie było uzasadnionych, a ile zostało po prostu przez nich zaakceptowanych post factum). Rodzice nie raz byli wzywani do szkoły "w sprawie syna”.

Swobodny stosunek Macieja Płażynskiego do obowiązków szkolnych wynikał z dużej potrzeby wolności osobistej, jaką wykazywał od dzieciństwa. Dlatego tak dobrze czuł się na łonie natury, w lesie, na łące, na jeziorze. Przyroda stanowiła dla niego przestrzeń do wyrażania swojej wolności. Chyba tylko dlatego akceptował coroczne rodzinne wakacje pod namiotem, zawsze w innej części Polski, bo wiązały się one z podróżami i przebywaniem wśród przyrody.

Był indywidualistą, który miał wielu kolegów, ale jednocześnie bardzo dobrze czuł się sam ze sobą. Szybko chciał być samodzielny w takim stopniu, jak to tylko możliwe. Umiał zresztą o siebie zadbać. Już jako bardzo młody chłopak podejmował się licznych prac dorywczych, dzięki czemu zawsze miał „swoje” pieniądze. W latach późniejszych odkładał je na podróże, jako dziecko kupował drobne rzeczy dla siebie oraz podarunki dla ukochanej mamy. Do wszelkich organizacji młodzieżowych - jak Związek Harcerstwa Polskiego - należał bardziej $\mathrm{z}$ przymusu niż chęci ${ }^{29}$. Dobrowolnie angażował się jedynie $\mathrm{w}$ inicjatywy sportowe, np. działalność Szkolnego Klubu Sportowego. Być może ucieczki ze szkoły czy z domu (zdarzało mu się nocować jeden czy dwa dni pod rząd poza domem, we własnoręcznie budowanych szałasach na łonie okalającej Młynary przyrody)

${ }^{28}$ Spostrzeżenia o zachowaniu się uczniów klasy VIIa na lekcjach, godzinach bibliotecznych, na ulicy, $w$ miejscach publicznych $i w$ domu. Prace społeczne uczniów, przynależność do organizacji szkolnych (funkcje), udział w kótkach zainteresowań, w zbiorach D. Płażyńskiej.

${ }^{29}$ Do ZHP (I Szczep Drużyn Harcerskich im. „Przyjaźni Narodów”, Hufiec Pasłęk) M. Płażyński należał od 1 IX 1969. Zob. Książeczka harcerska nr 391 druha Macieja Płażyńskiego, w zbiorach D. Płażyńskiej. Z książeczki harcerskiej wynika, że praktycznie nie angażował się w działalność ZHP, zdobył tylko jedną sprawność (Alert VII). 
były dla młodego Macieja formą demonstracji własnej odrębności i przejawem, w sumie dość łagodnym, buntu przeciw nadmiernej, jego zdaniem, dyscyplinie, którą w domu wprowadzali rodzice (zwłaszcza mama) i niemiecka opiekunka. W domu Płażyńskich panowała zasada szacunku wobec osób starszych, szczególnie rodziców. To do nich należało ostatnie zdanie. Przykładowo kolacja zawsze była o określonej porze i później żadne z dzieci nie mogło otrzymać już nic do jedzenia. Podobnie do końca szkoły podstawowej obaj bracia musieli kłaść się do swoich łózek tuż po zakończeniu telewizyjnej dobranocki. Tam mogli jeszcze czytać książki. Maciej z chęcią sięgał po lektury, zwłaszcza przygodowe i podróżnicze, do jego ulubionych autorów należeli Karol May i Arkady Fiedler, jednak obowiązek szybkiego kładzenia się spać musiał traktować jako ograniczenie swojej wolności. Nawet już jako dorosły mężczyzna zazdrościł żonie większej swobody, której rodzice w dzieciństwie i młodości pozwalali na dużo więcej ${ }^{30}$. W tym kontekście wagary, jako substytut otwartego sprzeciwiania się woli rodziców, można uznać nawet za samoograniczanie się Macieja Płażyńskiego, w którym rozgrywała się walka wewnętrzna między wyjątkową miłością i szacunkiem, jakimi darzył mamę, a potrzebą swobodnego decydowania o swoim losie. Ucieczki z domu, zwłaszcza na łono natury, były także efektem ciekawości świata, chęci przeżycia przygody. Te cechy, po następującym naturalnie w procesie dojrzewania „ucywilizowaniu”, zaowocały wkrótce pasją podróżowania, którą dorosły już Maciej Płażyński wykazywał się do końca życia.

Nic dziwnego zatem, że w charakterystyce ucznia Macieja Płażyńskiego, pod koniec jego edukacji w szkole podstawowej, w kwietniu 1972 r., czytamy:

Jest uczniem zdolnym lecz niezbyt pracowitym. Ulubionych przedmiotów nie ma. Interesuje się sportem. Do prac społecznych nie jest zbyt aktywny. Należy do ZHP i spółdzielni uczniowskiej, gdzie pełni funkcję kierownika działu gospodarczego. Do szkoły uczęszcza systematycznie. W tym roku szkolnym opuścił 4 dni, w tym 1 nieusprawiedliwiony. Stosunek rodziców do szkoły jest bardzo dobry, aktywny. Matka bardzo dużo pracuje w komitecie rodzicielskim ${ }^{31}$.

Jak wspomniano, braki w pracowitości niepokorny uczeń nadrabiał talentami. Stąd ośmioletnią wówczas szkołę podstawową ukończył w czerwcu 1972 r. z całkiem niezłym wynikiem. Uzyskał pięć ocen bardzo dobrych (sprawowanie, historia, biologia, chemia, wychowanie plastyczne), dziewięć ocen dobrych (język polski, język rosyjski, wychowanie obywatelskie, geografia, matematyka, fizyka, zajęcia praktyczne techniczne, wychowanie fizyczne, przysposobienie

\footnotetext{
${ }^{30}$ Notatka z rozmowy z E. Płażyńską, Gdańsk, 30 IX 2013 r., w zbiorach autora.

${ }^{31}$ Charakterystyka ucznia Macieja Płażyńskiego, Młynary, 15 IV 1972, w zbiorach D. Płażyńskiej.
} 
obronne) i jedną dostateczną (wychowanie muzyczne) ${ }^{32}$. Tym samym z końcem roku szkolnego 1971/1972 Maciej Płażyński przeszedł do historii jako absolwent Szkoły Podstawowej w Młynarach numer $893^{33}$.

W latach 1972-1976 Maciej Płażyński kontynuował naukę w Liceum Ogólnokształcącym im. Bohaterów Grunwaldu w Pasłęku. Podobnie jak w szkole podstawowej nie zawsze w stu procentach przykładał się do nauki, z którą nie miał jednak problemów. Był bardzo lubiany przez kolegów. Tomasz Chodnikiewicz, który poznał Płażyńskiego przez starszego brata Grzegorza, chodzącego z nim do jednej klasy, wspominał swojego przyjaciela:

On już wtedy grał w piłkę nożną, a ja w koszykówkę - - Był koleżeński i można było na nim polegać, zarówno w sprawach szkolnych, jak i sportowych. Najbliżsi koledzy pamiętają go $\mathrm{z}$ tamtych lat przychodzącego do liceum $\mathrm{z}$ teczką $\mathrm{i}$ „,Przeglądem Sportowym” pod pachą ${ }_{\imath}^{34}$.

W 1976 r. Maciej Płażyński zdał egzamin maturalny w LO w Pasłęku. Pasłęcki ogólniak dobrze zapisał się w jego pamięci. Tak naprawdę nigdy nie zerwał kontaktu $z$ tą szkoła. Z kolegami spotykał się na corocznych zjazdach towarzyskich. Już jako znana postać życia publicznego przyjeżdżał na spotkania z kolejnymi rocznikami uczniów, np. na 60-lecie placówki obchodzone w $2009 \mathrm{r}^{35}$ W czasach kierowania pracami Sejmu, gdy z racji nadmiaru obowiązków sam nie mogł wybrać się do Pasłęka, przyjmował delegację szkoły w parlamencie ${ }^{36}$. Z niektórymi przyjaciółmi poznanymi w Pasłęku los zetknął go w działalności na kolejnych etapach życia, np. Tomasz Chodnikiewicz w latach osiemdziesiątych był zastępcą Macieja Płażyńskiego w Spółdzielni Usług Wysokościowych „Świetlik”.

\section{Pożegnanie z Warmią}

Po zdaniu egzaminu dojrzałości Maciej Płażyński wrócił na kilka tygodni wakacji do rodzinnej miejscowości. Miał zapewne świadomość, że to jego ostatnie dni w Młynarach. W małej miejscowości nie mógł kontynuować edukacji ani znaleźć pracy, przynajmniej takiej, która odpowiadałaby jego ambicjom i planowanemu wykształceniu. Wkrótce czekały go egzaminy wstępne na studia wyższe.

${ }^{32}$ Świadectwo ukończenia Szkoły Podstawowej przez Macieja Płażyńskiego, Młynary, 15 VI 1972; Wyciąg z arkusza ocen, sprawowania i postępów w nauce ucznia Macieja Płażyńskiego za II okres w klasie ósmej, bdm, oba dokumenty w zbiorach D. Płażyńskiej.

${ }^{33}$ Absolwentem tej samej szkoły, o numerze 761, jest jego brat Wojciech. Obaj są zaliczani do najwybitniejszych osób, które uczęszczały do SP w Młynarach. Zob. 50 lat Szkoły Podstawowej..., s. 38 i 44.

${ }^{34}$ T. Chodnikiewicz, Kolega nie tylko ze szkoły, w: Moim powołaniem jest stużba publiczna..., s. 16.

${ }^{35} 60$ lat minęło..., http://www.zspaslek.edu.pl/index.php?option=com_content\&task=view\&id=128\&Itemid=1, 6 IV 2009, dostęp 1 VI 2015

${ }^{36}$ MS, W Pasłęku odsłonięto tablicę pamięci Macieja Płażyńskiego, http://wiadomosci.onet.pl/kujawskopomorskie/w-pasleku-odslonieto-tablice-pamieci-macieja-plazynskiego/lwwms, $20 \mathrm{~V}$ 2011, dostęp 1 VI 2015. 
Gdy w 1976 r. Maciej Płażyński przystępował do egzaminu dojrzałości, jego brat Wojciech, zgodnie z rodzinnymi tradycjami, był już studentem weterynarii na Akademii Rolniczo-Technicznej w Olsztynie. Maciej postanowił pójść inną drogą i po zdaniu matury złożył dokumenty na Uniwersytecie Gdańskim. Chciał studiować ekonomię, którą „czuł” dobrze jako obrotny chłopak, szybko zarabiający własne drobne pieniądze. Stolica Pomorza znajdowała się nieco dalej od stolicy Warmii, ale przyszły marszałek Sejmu znał Trójmiasto z wcześniejszych odwiedzin rodziny. Tu mieszkały jego ciotki - w Gdańsku Irena Płażyńska, a w Gdyni Hanna Ornatowska (z domu Płażyńska, siostra ojca). Zwłaszcza tą drugą bardzo lubił i miał z nią dobre relacje. Latem 1976 r. Maciej Płażyński przystąpił do egzaminu wstępnego na kierunku ekonomia, którego jednak nie zdał na tyle dobrze, aby zostać przyjętym na studia. Jak się okazało po ogłoszeniu szczegółowych wyników, poległ na zadaniu stricte matematycznym z rachunku różniczkowego i całkowego. Miał pecha, ponieważ była to akurat ta część programu z matematyki, której jego klasa w LO w Pasłęku nie zdążyła przerobić przed końcem roku szkolnego ${ }^{37}$.

Na szczęście, ponieważ edukację szkolną zakończył rok wcześniej od standardowej ścieżki szkolnej, po zdaniu matury w 1976 r. miał dwanaście miesięcy swoistego zapasu i bez obawy o wcielenie do wojska mógł pozwolić sobie na trochę luzu ${ }^{38}$. Uznał jednak, że jako człowiek dorosły, powinien zacząć żyć na własny rachunek, a chłopakowi w jego wieku, który ma twardy charakter, poznanie realiów prawdziego dorosłego życia nie zaszkodzi. A gdzie w Polsce lat siedemdziesiątych XX w. młody mężczyzna mógł szukać ciężkiej, męskiej pracy, jeśli nie na Śląsku? Wyjazdowi na drugi koniec kraju zdecydowanie sprzeciwiali się rodzice. Po pierwsze z racji odległości, po drugie chcieli, żeby syn przez rok przerwy w edukacji przygotowywał się do kolejnych egzaminów na studia wyższe. Maciej Płażyński postawił jednak na swoim. Trafił najpierw, w listopadzie 1976 r., na Dolny Śląsk, do Zagłębia Miedziowego, gdzie przeszedł nawet specjalistyczne badania lekarskie w Polkowicach umożliwiające pracę pod ziemią. Jednak już po kilku dniach, prawdopodobnie nawet nie podejmując pracy, przeniósł się na Górny Śląsk i tam przez prawie 12 miesięcy pracował jako robotnik niewykwalifikowany. Śląską (a ściśle rzecz biorąc, pod względem geograficznym zakotwniczoną w Zagłębiu Dąbrowskim) szkołę życia Płażyński rozpo-

\footnotetext{
${ }^{37}$ Relacja D. Płażyńskiej...

${ }^{38}$ Co ciekawe, później wcielenia do „ludowego” wojska uniknął dzięki załatwieniu sobie fałszywego zaświadczenia lekarskiego o niemożności odbycia służby wojskowej. Jak sam wspominał po latach, „w normalnych warunkach” z chęcią poszedłby do wojska, a nawet został zawodowym żołnierzem. W pracy wojskowego podobało mu się operowanie konkretem, wydawanie decyzji, ich wykonywanie i egzekwowanie. Jednak w państwie komunistycznym, jak podkreślał, „wolałby pójść do więzienia niż do wojska”. Relacja E. Płażyńskiej, 8 III 2014, w zbiorach autora.
} 
czął 25 listopada 1976 r. ${ }^{39}$ Pracował m.in. przy budowie Huty Katowice w Hutniczym Przedsiębiorstwie Remontowym. To była jedna z największych inwestycji w PRL dekady Edwarda Gierka. W czasie gdy pracował tam Maciej Płażyński, budowa huty wkraczała w kluczową fazę. Uruchomiono po raz pierwszy najważniejsze elementy zakładu - walcownię, stalownię i pierwszy piec hutniczy, w którym wytopiono pierwsze tony stali. Płażyński niemal przez rok zatrudniony był jako pracownik fizyczny w Hutniczym Przedsiębiorstwie Remontowym i Przedsiębiorstwie Usług Stalowych „Budostal“ w Dąbrowie Górniczej. Wtedy poznał smak życia w hotelach robotniczych. To chyba właśnie ten rok pracy na południu Polski zadecydował o jego sentymencie do Śląska (jako późniejszy parlamentarzysta $\mathrm{z}$ Pomorza utrzymywał w pewnym okresie filię swojego biura w... Jastrzębiu-Zdroju). Te doświadczenia i zatrudnienie w drugiej połowie lat osiemdziesiątych w Spółdzielni Usług Wysokościowych „Świetlik“ (później "Gdańsk") przyczyniły się też do zrozumieniu i dobrych relacji z ludźmi pracy. Blatego Maciej Płażyński tak doskonale w swojej działalności publicznej po 1989 r. wyrażał ideały i interesy "Solidarności“' (mimo ze sām formalnie nigdy nie był członkiem Związkư ${ }^{40}$.

Po rocznym pobycie na Śląsku Płaźyński zdał egzaminy i zostal przyjęty na Wydział Prawa Uniwersytetu Gdańskiego. Wraz z początkiem roku akademickiego, jesienią 1977 r., wyjechał z Młynar, jak się okazało, na zawsze. Jednak nawet po przeprowadzce rodziców do Ornety, gdy w małej miejscowości nad Baudą nie było już rodzinnego domu, lubił do niej wracać, np. zbaczając nieco z drogi z Gdańska do Warszawy, którą często pokonywał w latach dziewięćdziesiątych w związku z wykonywanymi funkcjami publicznymi. Czuł się związany z lokalną społecznością, a ta widziała, że znamienity krajan nie zapomniał o niej. Gdy tylko pozwalały mu obowiązki i czas, uczestniczył w ważnych wydarzeniach z życia Młynar ${ }^{41}$. Maciej Płażyński uznawany jest za najwybitniejszego mieszkańca tej miejscowości w historii. W dniu 5 listopada 1994 r. Rada Miasta nadała mu tytuł Honorowego Obywatela Miasta Młynary ${ }^{42}$.

\footnotetext{
${ }^{39}$ Kartoteka kontrolna BHP Macieja Płażyńskiego, bdm, w zbiorach D. Płażyńskiej. W trakcie pobytu na Śląsku M. Płażyński wyjechał krótko do Suwałk, skąd wrócił do pracy na południu Polski.

${ }^{40}$ Zdecydował o tym życiowy przypadek i wiek. Gdy powstała „Solidarność”, był za młody. Nie pracował, tylko studiował, dlatego został członkiem Niezależnego Zrzeszenia Studentów. Po reaktywacji Związku w 1989 r. Płażyński był już urzędnikiem państwowym i politykiem, a więc niejako pracodawcą, któremu w pewien sposób nie wypadało angażować się w działalność związkową.

${ }^{41}$ Przykładowo 4 IX 2001 r. M. Płażyński uczestniczył w uroczystym rozpoczęciu roku szkolnego 2001/2002 w Szkole Podstawowej w Młynarach.

42 J. Białobrzeski, op. cit., s. 343. Co ciekawe, w Młynarach w 1959 r. urodził się również znany dziennikarz Jarosław Gugała, który później został doradcą M. Płażyńskiego, gdy ten pełnił funkcję marszałka Sejmu III kadencji.
} 


\section{Bibliografia}

Źródła archiwalne

Instytut Pamięci Narodowej, Oddział w Gdańsku

IPN Gd 0046/54 t. 1, Wykaz oświadczeń ujawnionych członków organizacji politycznych działających w okresie okupacji, Gdańsk, 20 V 1965.

Archiwum rodzinne Danuty Płażyńskiej

Spostrzeżenia o zachowaniu się uczniów klasy VIIa na lekcjach, godzinach bibliotecznych, na ulicy, $w$ miejscach publicznych $i w$ domu. Prace społeczne uczniów, przynależność do organizacji szkolnych (funkcje), udział w kółkach zainteresowań.

Książeczka harcerska nr 391 druha Macieja Płażyńskiego.

Charakterystyka ucznia Macieja Płażyńskiego, Młynary, 15 IV 1972.

Świadectwo ukończenia Szkoły Podstawowej przez Macieja Płażyńskiego, Młynary, 15 VI 1972.

Wyciag z arkusza ocen, sprawowania i postępów w nauce ucznia Macieja Płażýnskiego za II okres w klasie ósmej.

Kartoteka kontrolna BHP Macieja Płażyńskiego.

Wywiady (w zbiorach autora)

Relacja D. Płażyńskiej, 8 III 2014

Notatka z rozmowy z E. Płażyńską, Gdańsk, 30 IX 2013 r.

\section{Literatura}

50 lat Szkoły Podstawowej im. Stefana Żeromskiego w Młynarach, bdm.

Białobrzeski J., Młynary. Małe miasto 1327-2007, Olsztyn 2008.

Chmielecki A., Dzieciństwo, miłość, rodzina, [w:] Moim powołaniem jest służba publiczna. Rzecz o Macieju Ptażyńskim, red. Andrzej Grzeszczuk, Anna Dudzik, Izabela Paczesna, Warszawa 2013.

Chodnikiewicz T., Kolega nie tylko ze szkoty, [w:] Moim powołaniem jest służba publiczna. Rzecz o Macieju Płażyńskim, red. Andrzej Grzeszczuk, Anna Dudzik, Izabela Paczesna, Warszawa 2013.

Ewertowski S., Kulturowy i gospodarczy wymiar „świętych miejsc" regionu Warmii i Mazur, Studia Warmińskie, 2010, nr XLVII, ss. 109-122.

Konopczyński W., Dzieje Polski Nowożytnej, Warszawa 1996.

Korsak J., Człowiek z Młynar, [w:] Moim powołaniem jest służba publiczna. Rzecz o Macieju Płażýnskim, red. Andrzej Grzeszczuk, Anna Dudzik, Izabela Paczesna, Warszawa 2013.

Ludność. Stan i struktura w przekroju terytorialnym. Stan w dniu 30 VI 2012 r., Warszawa 2012.

RP, Marszałek na cmentarzu, Gazeta Wyborcza. Lublin, 7 XI 2000.

Sieradzon J., Skok do piekła i do nieba w lipcu 1944 r., Biuletyn Informacyjny Światowego Związku Żołnierzy Armii Krajowej Okręg Wielkopolska, 2008, nr 3, ss. 37-43.

Wojtkowski J., Kapłani Archidiecezji Warmińskiej zmarli w latach 1992-2002, Studia Warmińskie, 2003, nr XL, ss. 471-511.

Strony internetowe

60 lat minęło.., http://www.zspaslek.edu.pl/index.php?option=com_content\&task=view\&id=128\&Itemid=1 (dostęp: 6 IV 2009).

Biogram Maksymiliana Płażyńskiego, Wykaz Legionistów Polskich 1914-1918, Muzeum Józefa Piłsudskiego w Sulejówku, http://mjp.najlepszemedia.pl/wykaz-legionistow/wykaz/legionista/19859-plazynski. 
Brat Macieja Płażyńskiego, Wojciech Płażyński: Żegnaj Braciszku!, Se.pl, http://www.se.pl/wiadomosci/ polska/brat-wojciecha-plazynskieg-zegnaj-braciszku_136526.html (dostęp: 16 IV 2010).

Historia Młynar, http://www.mlynary.pl/index.php?pod_menu=12.

Klub Sportowy Syrena Młynary, http://syrena.futbolowo.pl/menu,2,o-klubie.html.

MS, W Pasłęku odsłonięto tablicę pamięci Macieja Płażyńskiego, http://wiadomosci.onet.pl/kujawskopomorskie/w-pasleku-odslonieto-tablice-pamieci-macieja-plazynskiego/lwwms (dostęp: $20 \mathrm{~V} 2011$ ).

Oddziat „Nerwy” - młodzi, dzielni, niezapomniani, http://www.gimlbychawa.pl/downloads.php?cat_ id=9\&download_id=41.

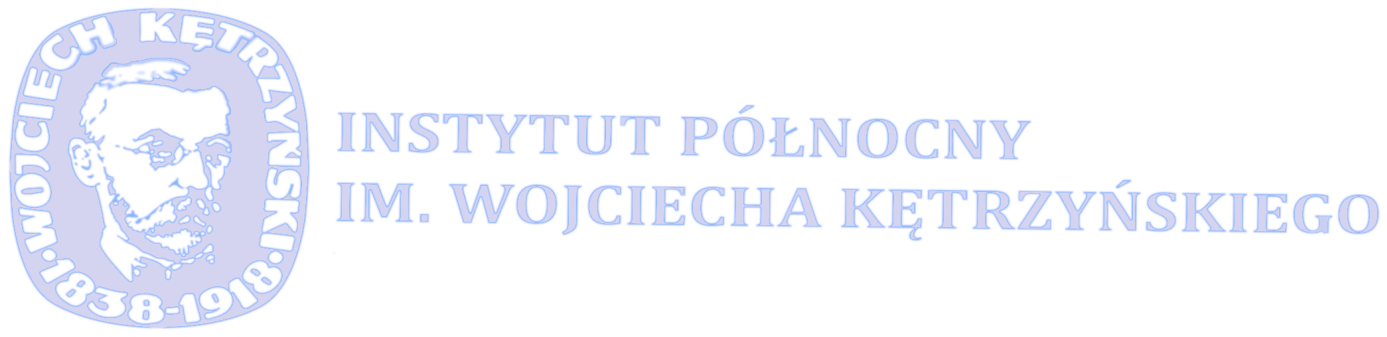

